\title{
Bile Duct Epithelium
}

National Cancer Institute

\section{Source}

National Cancer Institute. Bile Duct Epithelium. NCI Thesaurus. Code C43616.

The epithelium of the bile duct, which consists of cuboidal cells called cholangiocytes. 